\title{
ABOUT THE REGENERATION OF THE EUROPEAN TYPE OF CIVILIZATION
}

\author{
Werner MÜLLER-PELZER, PhD \\ University of Applied Sciences and Arts Dortmund, Germany \\ werner.mueller-pelzer@fh-dortmund.de
}

\begin{abstract}
Europe is an omnipresent topic of public debate, but the discussion runs wrong due to two main errors: 1. Today, Europe and the European Union would mean one and the same thing, called "European project". This misconception relies on error 2. The scientific reconstruction of European history that has led to this state of affairs would be cum grano salis consensual. - The intention of the following text is to give some hints to falsify these presuppositions. The key argument is the disclosure of the "half empiricism" which is the congenital defect of occidental philosophy and science, mainly interested in liberating cognition from troubling influences and subjective feelings. With reference to the New Phenomenology founded by Hermann Schmitz (2009, 2011), the plan to regenerate Europe will have to begin with telling, suggestive impressions of the pre-reflexive corporeal experience, paradoxically telling more than one can say. It is a sensitivity for specific situations which have made the European type of civilization. The text explains that learning an unknown European language on the base of encorporation (Einleibung) during the "European semester" will help to regenerate this European sensitivity. To be successful, the new programme will be independent from the main antagonists: globalist interests, associated political forces and anti-European ideologies. In the focus of renewal are the smaller European countries, their languages and their contribution to the European style of civilization, hidden by the "big five" Germany, UK, France, Spain and Italy. In the phenomenologically informed perspective of the new MONTAIGNE student exchange programme, language acquisition will be understood as world acquisition. The "European semester" will be entirely dedicated to it.
\end{abstract}

Keywords: European project, New Phenomenology, European semester, MONTAIGNE programme.

\section{Europe and the European Union}

The institutional weakness of the present EU is undeniable. Several authors recently have presented their ideas, from Germany for instance Klaus Weber / Henning Ottmann and Frank 
Decker (Weber and Ottmann, 2018, pp. 59-76). In a very summarized way their propositions for a renewed EU are: Smaller, less centralized, more competences to the national parliaments

Other experts, nevertheless, are asking: Is it enough to reform the EU, knowing that the finality of the European integration is still uncertain? (Sloterdijk 1994, 2004). To scientific research, it is a puzzling phenomenon that in the world of economic and political power "Europe" seems to belong to the global players, but in opposition to the other members of that "ivy league" Europeans don't share a conviction about their common affective roots (Sloterdijk, 2006, pp. 365374). The functionalist layer of EU and the national traditions (history, geography, religion, science, law, politics, economy, culture) don't have met to fuse into a common ideology. This dilemma provokes political voluntarism, - a popular tradition in France, now reborn with the project of Emmanuel Macron. With his programmatic speech "Refonder l'Europe", (Macron, 2017 ) the French President gives a brilliant example of melting EU and Europe in the "European project". He insists in the European identity quoting various historical, philosophical and cultural achievements and the voices of outstanding artists: With this rhetoric impetus Macron passes over to the political reality of today pleading for a "souveraineté européenne". Meanwhile in this fusion some representatives of EU elites see an encouraging new beginning, an attentive analyst mainly recognizes a confusion that is meant to instrumentalize Europe for political strategy; the satirist would even criticize a "Disney-Europe" with a wonderful collection of artistic and intellectual highlights as if these would enable EU to be a strong global player (Müller-Pelzer, 2018).

Macron's eloquence is in line with other intents to launch a top-down identity feasible to give an imagined demos and with it to compensate the lacking legitimacy of EU politics. In analytical terms there are three types of argumentation:

1. The Identity discourse: "Europe and the European Union are one and the fusion of both is the 'European project'”. Critique: To identify Europe with the EU is the launch of an unfriendly take-over on Europe. Europe and EU must neatly be distinguished:

- The EU is an institution created by several Nation-States. It consists of a great number of organizations. The European Union is a functional construct.

- $\quad$ Europe is no institution; it is no functional construct; it is no organization. Europe was first identified with Christianity, then with the attitude to interpret life in dialogue with historical references of the Greco-Roman past, then with cultural resources (Arts, Science, Law, 
army, secular and ecclesiastical authorities etc.). The resulting cultural system, despite its profound internal differences, refers to the common origin of the self-containing critical spirit.

- The EU has declared its will to protect European values as democracy, rule of law, tolerance, freedom, equality, and Human rights. But the claim to be the inheritor of European values is exaggerated: The EU is not their author and incapable to guarantee profound affective ties from which value attitudes emerge. The feeling and consciousness of common values relies on uncountable diffuse but characteristic experiences in common implanting situations, not on discourse.

When Europe is challenged, a similar type of questions as those of ancient Greek polis arises: "What kind of European do I want to be? What kind of living together as Europeans do we want to pursue? What kind of Europe do we want to create?" The European type of civilization demands the public scrutiny and refuses the delegation of the European raison d'être to functional elites and post-democratic governance.

2. The Democracy discourse: "The EU is a democratically legitimated political entity." Critique: The democratic legitimation of EU institutions is much lower than that of national democracies, suffering themselves under a loss of democratic recognition.

- The EU construct mainly is the result of the two Maastricht and following treatises, signed by democratically elected representatives of the respective nation-states. But the democratic legitimacy of the government, e.g. in Germany, is weak because the nomination of candidates for the national Parliament by the political parties and the mixed electoral system show a considerable lack of transparence(Herbert von Arnim, 2009). Additionally, the lack of transparence of the nomination of candidates for the EU Parliament elections is notable, only surpassed by the obscure nomination of candidates for the EU top jobs.

- The separation of powers is not realized in the EU construction: The European Commission and the European Council may constitute a part of the new multi-level governance, but there is no hope for the emergence of a new democratic legitimation. Above all, the European Supreme Court claims for its decisions the "competence-competence" concerning the European treatises and, thus, is modeling the EU without a sufficient democratic legitimation (Grimm, 2016). 
- $\quad$ The EU is not just the continuation of the Europeans Communities but, since the Lisbon Agenda of 2000, a global player with worldwide strategic interests. This profound transformation, in fact a refoundation hidden to the citizens, contributes to a complementary weakening of democratic legitimation through national elections: National competences are increasingly transferred to EU so that the national state is losing more and more the role of the citizens' interlocutor. The moralizing EU value discourse can't compensate this deficit.

3. The Cosmopolitist discourse: "The governments of EU members are right in construing a transnational political union of Europe to overcome internal discordance, breading nationalism, and to focus on a universal democratic governance." Critique: The European nations should not be made the scapegoat for the crimes of $20^{\text {th }}$ century's military and economic elites.

- To push a political European identity to prevent classical war is inadequate. The commercial and economic cooperation is so strong that in Europe nowadays war is fairly excluded. On the contrary, the suppression of national structures, instead of resolving pressing problems, has created new ones: The decrease of political and cultural autonomy has created the impression of heteronomy and provoked a fallback to obsolete nationalist resentments. There are serious voices that maintain: The greatest danger for peace and public wealth comes from the ECB monetary politics (Streeck, 2015, p. 41).

- $\quad$ Following G. Bouchard, (Bouchard, 2016, pp.40-43) it is misguiding to blame the European nations for the horrors of the first half of $20^{\text {th }}$ century: One should better focus the responsibility of the European elites eager for power and depreciating the peoples.

- Under these conditions one shouldn't ignore that until now all functionalist topdown procedures to introduce a common identity have failed (Bouchard, 2016, p.33). A bottomup procedure, then, is needed. Bouchard pleads to begin with asking the European nations in which way they have established lasting affective ties with Europe; one should add: to discover the underlying normative programmes that make the difference with other types of civilization.

Coming back to the central question of inquiring the shared conviction about the common affective roots, the above examination shows that the current proposals don't have contributed to a better understanding. One necessary condition seems to keep away a specific political purpose like finding arguments for strengthening the legitimation of EU institutions. For a better understanding how collective affective evidences and convictions grow as well as how they 
degenerate, a specific approach is needed which allows to seize those pre-reflexive phenomena the normal scientific disciplines are not able to get in touch with (Gehler, 2018).

A phenomenological approach to Europe pretending to overcome the "half empiricism" needs explanation because the occidental philosophical tradition has been hostile to pre-reflexive phenomena.

\section{Europe - a philosophical subject}

The European type of civilization refers to the emergence of an, as far as that, unknown human attitude toward reality in ancient Greece. Only with the practical and political consequences of this occidental type of civilization, Europe could become a subject for historians. It is not superfluous to mention the decisive naval battle of Salamis in 480 BC: The clash of the Greek type of civilization with the oriental type has also become crucial for the self-perception of Europeans.

In the perspective of cultural morphology, high cultures require a special discipline of the elites to form and stabilize civilization(Schmitz, 1997, p. 23).

a. Near Eastern High Cultures (Egypt, Babylonia, Persia): discipline is guaranteed by the divine authority of princes and priests.

b. Far Eastern Cultures (China, Japan): discipline is guaranteed by the power of convention, rules and rites of decency.

c. European High Culture (Greece): discipline is based, very differently, on the discipline to oblige the individual to form its own judgment and, on this base, to submit propositions about individual and common life, grounded on arguments that are exposed to the critique of the others. It is the model of the self-containing critical spirit through discussion. The result is a philosophical style of self-examination: "Know thyself" (inscription of the Apollo temple in Delphi) plus the exhortation to the individual: "Be careful" ( $\Sigma \omega \varphi \rho$ óvє1) when searching the appropriate, human proportion, i.e. neither to overestimate nor to humble himself. Neither to be dominated by others nor to dominate others, is the political lesson attributed yet to Herodotus.

The European type of civilization is the result of transferring the occidental type to countries to the north of the Mediterranean Sea, inheriting this rejection of the oriental domination by despots and priest castes. This equally applies to the Christian and the Islamic absolutism to dominate society. Being European, then, is anchored in a philosophical attitude toward reality, the discipline of self-containing critical spirit, even if for some centuries it seemed to have been fallen 
into a crevasse (Michael Mitterauer). This spirit contributes to detect that Europe has inherited, too, a lot of philosophical failures from Greek philosophy.

The main failure is the destruction of suggestive impressions and the reduction of perception to a half empiricism. In a simplified manner, the following table will illustrate this crucial failure.

Table 1

\begin{tabular}{|c|c|}
\hline \multicolumn{2}{|c|}{ Evidences in occidental tradition } \\
\hline Invisible $=$ diffuse & Visible $=$ full determined \\
\hline Feeling $=$ deception, & Seeing $=$ knowledge \\
\hline ignorance & Intellectual = stable \\
\hline Corporal $=$ transitory & Rational judgment $=$ true \\
\hline Sensations $=$ fallacious & Reflexive $=$ controllable, \\
\hline Pre-reflexive & repeatable \\
\hline uncontrollable & Superior value \\
\hline Minor value &
\end{tabular}

Evidences in occidental tradition [own chart, W.M.-P.]

This table reflects the post Democritian-Platonican reductionism depreciating the former way of perceiving the world through telling impressions (vielsagende Eindrücke) (Schmitz, 1995, pp. 19-118). The feeling and felt body, the corporeal communication, the feelings as powerful atmospheres are lacking or distorted into a psychic reality. H. Schmitz has split the process in three phases: (Schmitz, 1995, p.16).

1. Psychologism: The Homerian heroes are victims of various impulses and stirrings (of supposed divine origin); the person who says "I" is weak. With Democritus and Plato, the "I" 
becomes the master of these impulses and stirrings: The psyche turns to be an inner world (soul) opposed to the outer world of bodies. Additionally, the construct of a rational part of the soul is meant to explain the struggle with "irrational" impulses.

2. Reductionism: The dynamics of reality, the telling impressions, are reduced to a kinetics of atoms or abstract substances with qualities and relations. The hierarchy of abstract categories reflects the canonic significance of the distant, cognitive approach to reality in occidental thinking.

3. Introjectionism: What cannot be seized following this method, remaining inappropriate for abstraction, counting and statistical use, will be disposed in the inner world. The holistic experience is smashed. But in reverse order, the reconstruction of telling experiences from a cognitive base will be impossible because of the supposition that the world stuff consists completely of countable elements.

Today, against these failures the neo-phenomenological approach opposes the sensing of affecting experiences in the epistemological perspective, i.e. that the surrounding world has something to say to me, be it by corporeal resonance, be it by deep atmospheric movements or overwhelming experiences. In an ontological perspective, affective reality is "always there" before focusing a special subject. Paraphrasing Hermann Schmitz, this feeling of one's own movements and the contacts with others and the surrounding world follows not the model of registration and deciphering of data. The main instance of orientation in the world is the feeling and felt body (Germ. der Leib, Fren. la chair, Span. la carne). So, the communication and interaction is corporeal, (Schmitz, 2011) to the baby in a total way, to the youngster in a "rocking and rolling" way and to the adult in a mixed way, swinging between the personal emancipation from the "jail" of corporeal dependence and the personal regression, obliging the emancipated subject to come down from a high level of autonomy to affective states of pain, sorrow, shame, anger, passion etc.

"[...] the feeling body becomes manifest in holistic corporeal stirrings such as vigor and languidness, in one's being corporeally gripped by emotions and room-filling atmospheres, and equally in one's corporeal orientation in the world in contexts of perception, action and spatial navigation.”(Müllan and Slaby, 2011, p. 244)

The negation of this pre-cognitive orientation of humans in the world has blocked occidental philosophy to consider a pre-reflexive unity of subject and object without distinction. Destroying this unity and only accepting the distanced cognitive approach to reality has been mainly responsible for the limitations of occidental philosophy in comparison with Eastern 
wisdom. It is the affectivity by which something arises in our field of perception as a carrier of meaning or value. Feelings are ways of taking part in the world, they are opening the world even before cognitive operations become virulent. But on the other hand, the reference to the world is always linked with a self-reference. In corporeal sensations, the world opens under a specific perspective where something manifests itself as significant ("It does concern me.") or as indifferent ("It does not concern me."). Affectivity is the decisive note that makes that "something matters" in personal and common situations (Salby, 2010, p.3). The key point, then, is that the individual is moving in a pre-reflexive area, or better: belongs to a pre-dimensional space (Scmitz, 2005, p. 283) which is also constitutive for the common situations, i.e. the surrounding world the individual is living in with others (Müllan and Slaby, 2011, p. 245). Especially feelings are the motor of personal life, making objectives attractive or mobilizing against repulsive or revolting states of affairs. The fading-out of this part of human experience makes that Europeans of today are living in a half reality and, with it, in an abstract Europe cut from affective implication.

\section{Situations versus constellations}

Being-corporeally-in-the-world is being-situated in a specific context and implies a subjective perspective: We don't speak about a brain being somewhere in the universe, but of a feeling and felt body embedded in situations. "Situation" is a terminus technicus of H. Schmitz" social philosophy; it means the characteristic, but internally diffuse and suggestive impressions detached from the background of everyday life: the expressive atmosphere of a room (e.g. a church, a Japanese garden, a holy grove, the German type of Gemütlichkeit), then all types of lieux de la mémoire nationale et européenne, the first impression of an unknown person or city, but also the more enduring character of an interlocutor or the spirit of a social milieu or a people. ${ }^{1}$

For the current scientific positivism these phenomena are perhaps interesting, but subjective and insignificant. What counts are objective data feasible to be formatted and

\footnotetext{
${ }^{1}$ In opposition to more distant civilizations, there is no reason to suppose that the socially and historically settled and practiced "grammar" of feelings could include unfamiliar "blanks" with the consequence that the corporeal communication would break down. Hermann Schmitz (2010): "Entfremdung und Urfremdheit", in : Idem (2010) : Jenseits des Naturalismus, Freiburg / München: Karl Alber, pp. 333-348 ; Hilge Landweer (1995): "Verständigung über Gefühle", in: Michael Großheim (Hg.) (1995): Leib und Gefühl. Beiträge zur Anthropologie, Berlin: Akademie, pp. 71-86.
} 
statistically treated. This realism (Sachlichkeit) rules the world of objectivity, but the world of subjectivity and affectivity, the significativity of objects, persons and situations pales.

Reduced to constellations, impressions become a façade without connection with the affective origin. The economic globalization together with high-tech applications (digitalization, artificial intelligence) is invading areas that seemed reserved to privacy and being secure from algorithms (Illouz, 2018). Obviously, Europe as an implanting affective reference and the European Union as a global player are two different worlds, run by different logics. Penetrating common life with the ideology of growthism (Daly, 2015) and global competitiveness, the selfinterpretation of Europeans and their reciprocal relations suffer from alienation. The ERASMUS students exchange programme is contaminated with this constellationism.

The acronym of the European community action scheme for the mobility of university $\underline{s}$ tudents shows that the student mobility is considered as one of the drivers for European technological and economic leadership. To embed these objectives in a wider conception, Jacques Delors had launched the idea to establish the ERASMUS-programme. His intention was to combine professional and personal development with social and environmental responsibility. For Delors, Europe should become " $[\ldots]$ un espace de paix active, un cadre pour un développement durable, et enfin un espace de valeurs vécues dans la diversité de nos cultures et de nos traditions. » (Delors, 2004, p.462) Meanwhile, the political climate has changed; the actual speeches of EU politicians resemble more and more to a caricature of Delors' initial intentions (Merkel, 2017). Today, the ERASMUS programme has become a catalyst of "human capital individualism" (Münch, 2008) without any reference to the affective reality of the European type of civilization. The telling impressions, the original stuff of unfiltered intercultural experience, is channeled in the interest of smooth transcultural adaptation for future employment. 
For this reason, the purpose of the present paper is to present a reasonable alternative for mature European elites, called the MONTAIGNE programme. ${ }^{2}$ It will take advantage from acquiring an unknown European language on the ground of encorporation (Einleibung). ${ }^{3}$ This plan has to overcome two main obstacles: to get an access, at the age of about 20 years and more, to the infantile learning method reputed to run only till the age of about 13 to 15 years; and second, to present good arguments to propose for election exclusively the lesser spoken languages.

- Recognition: To learn a lesser spoken European language of a country not belonging to the politically dominant "big five" is an act of recognition of worth concerning the contribution to the regeneration of the European type of civilization. This decision is enriched with an incomparable mass of atmospheres calling for a powerful and lasting corporeal resonance in the addressees and an intense corporeal communication (Honneth, 2018).

- $\quad$ Change of perspective: The unconventional method of blended learning (a new format built from elements of infantile method and adult method) means to enact the structure of personal existence described by New Phenomenology, i.e. to practice the mentioned changes from higher levels of personal emancipation to lower levels absorbing experience from personal regression. This change of perspective can be considered to make the individual composure more flexible and, thus, to discover step by step the own style of being instead of applying general concepts of desensitization like resilience (Slaby, 2016, pp.273-298). This, besides, comes near to the "self-essaying" advocated by the historical MONTAIGNE.

\footnotetext{
${ }^{2}$ The denomination ERASMUS programme stems from the acronym European community action scheme for the mobility of university students. Since the 1980s mobility had become a central educational objective for exporting countries. The decision to allude to the Dutch humanist has been taken for marketing reasons: At that time, the play with the name of the emblematic humanist had been considered useful. Today, not just for marketing, but for historical reasons, there are two motives to prefer the name of MONTAIGNE. The first is the fact that the intellectual departure of modern Europe in $16^{\text {th }}$ century finds the most appropriate expression with a jurist-writer-philosopher as Michel de MONTAIGNE (1533-1592). He had overcome the reassuring limits of the Christian humanism of ERASMUS of Rotterdam and had experienced the turbulences of a world, having lost the traditional orientation in metaphysical, political, scientific and anthropologic respect. The second reason is that in his Essais, MONTAIGNE writes in French, a vernacular language, and not in Latin he perfectly dominates. Thus, MONTAIGNE witnesses that being European is inevitably linked with the acquisition and practice of a living language (or more). So, he represents two principles which make the European of today, i.e. the self-containing critical spirit of the European type of civilization, and the implantation in pre-reflexive situations (Lebenswelt) nurtured by a national language and ancient European traditions. In this respect, the MONTAIGNE programme fits better for a student exchange programme.

${ }^{3}$ I.e. to sense the feeling and felt body (Leib), to rediscover the corporeal communication (leibliche Kommunikation), and especially the antagonist encorporation as well as the encorporation in solidarity (antagonistische und solidarische Einleibung).
} 
- $\quad$ Survival of high level languages: Following the analysis of Jürgen Trabant (2014) concerning the future of European languages in the standardized world of global English, the MONTAIGNE programme may represent one of the last chances for the lesser spoken European languages to survive as high level languages. This type of language means to serve all cultural purposes including Art and Science, contrasting with vernacular languages used only for domestic purpose.

\section{The European semester - from language acquisition to a European feeling of life (Lebensgefühl)}

The political misuse of European values for tactical purpose has transformed the history of blood, sweat and tears to dead letter. In fact, the vitality of European values relies on embedding, emotionally grounded situations enabling the individual to say: "I want to be free. This is not right. I cannot act against my convictions. I will get to the bottom of this. I cannot be corrupted by advantages. This contradicts my European attitude."

My thesis is the following: Recent research has shocked the rule of "windows" for infantile language learning method in affective terms. Performative approaches to language learning, according to the affective implication a privileged role, have contributed to good results with young adults, under the condition to abandon the conventional school teaching type (Crutchfield and Schewe, 2017). In the phenomenological perspective, the successful integration of the prereflexive resonant experience into language learning relies on encorporation (Einleibung following H. Schmitz), the basic corporeal communication and interaction with the surrounding world. In this respect language learning is closer to slip into a Lebensgefühl (Großheim, Kluck and Nörenberg, 2014) than to reach the highest degree of language proficiency, i.e. linguistic and pragmatic competencies, defined in the Common European Framework of Reference for Languages (CEFRL). The Council of Europe sees this as the main part of the project "Language Learning for European Citizenship". The CEFRL is a useful facilitator of student mobility worldwide, but it consecrates and accelerates with it the international run for the best professional chances. It promotes the model of "human resource individualism" (Münch, 2008), the pointed contemporary form of social autism. 
This new European exchange programme will not include English, German, French, Spanish and Italian (as target languages!) because they are learned extensively and intensively in secondary and adult education. In the MONTAIGNE programme, the invitation to learn an unknown language starting from scratch avoids interferences from earlier learning experiences. The idea is to have a "blind date" with Europe, just roughly filtered by five groups of available European languages. ${ }^{4}$ In this way, the lesser learned languages will come to their right and will place their rich and unknown wisdom at all Europeans. The "European semester" will be open to all university courses and faculties. It will be dedicated completely and in diversified ways to language acquisition conceived as the acquisition of a facet of European Lebensgefühl. There will be no other study courses. ${ }^{5}$

Language acquisition will be one decisive key for entering an unknown cultural, affective and linguistic common situation, challenging the corporeal resonance as well as the room for manœuvre of personal emancipation from overwhelming feelings (Germ. Ergriffenheit). The prereflexive corporeal space will be activated by performative methods, knowing that pre-reflexive experience is the interface of individual and collective feelings with verbal expression. Jürgen Trabant's metaphor of a "brother language" (and one could add, in analogy, "sister language") is appropriate to highlight the affective character of beginning to move in another language; nevertheless, in the phenomenologically trained perspective, Trabant's expression will even gain a more specific sense.

Following the insights of Hermann Schmitz (2012, pp. 207-277) speaking is, firstly, not using language as an instrument for a practical or theoretical purpose. Imitating the cries of animals, shouting in a working, marching or struggling context contributes to encorporation in common situations. This is the inclusive function called "corporeal intelligence" (Schmitz, 2012, pp. 213). To cultivate and extend this competence is meant to create a background the learner is able to sense and to adapt to spontaneously: More or less expressivity in gesture and mimic, ways

\footnotetext{
${ }^{4}$ Group 1: Russian, Ukrainian, Bulgarian, Greek, Armenian, Georgian, Group 2: Macedonian, Serbian, Croatian, Slovenian, Czech, Slovak, Polish; Albanian, Montenegrin and Bosnian-Herzegovinian would be excluded for practical reasons ; Group 3: Finnish, Estonian, Latvian, Lithuanian, Hungarian ; Group 4: Icelandic, Scottish, Gaelic, Irish, Norvegian, Swedish, Danish, Dutch ; Group 5: Portuguese, Galician, Basque, Catalan, Romanian.

${ }^{5}$ A detailed curriculum with a preparative European module is yet available. See Werner Müller-Pelzer (2019): Europa regenerieren. Über das Entstehen kollektiver Atmosphären (forthcoming).
} 
of laughing, giggling or keeping silent, way of looking to each-other, proxemics, ways of group behavior, etc.

On the other hand, the specific human capacity consists of speaking in sentences (not necessarily in the grammatical sense), understood as taking some relevant facts out of characteristic, but internally diffuse situations, binding them together to constellations and taking a partial distance toward an obsessing affectivity. This is the explanatory function called "hermeneutic intelligence", trying to make explicit (to singularize) states of affairs, programmematic parts and problems of the respective situation. The exclamation of surprise "Gosh!", e.g., refers to well-known situations and will be transferred to other contexts, be it right or wrong. "Es gab einen Mordskrach!" characterizes a huge standoff between persons, but with it a specific atmospheric conflict in the perspective of an observer. "Impossible n'est pas français." may be uttered in different situations and with different affective connotations.

The learning method designed for the MONTAIGNE programme plays with these two facets of speaking another language. Meanwhile the conventional learning method for adults depends on the - erroneous - presupposition of language as a system (Schmitz, 2012, pp. 213) and employs the "analytical intelligence" to apply grammatical etc. rules, the present method focusses the affectivity of common situations, be it in an inclusive or an explanatory way. As a tribute to the adult learners which are familiar with the conventional method from previous language learning experiences, the MONTAIGNE method, nevertheless, considers also a rule-based perspective; otherwise one would provoke intellectual dissatisfaction among students. Additionally, the analytical approach facilitates transfer, accelerates the learning processes and gives more autonomy to the learner.

Playing with the change between the including and the explanatory perspective, the students will develop the mentioned sensitivity for atmospheres when dealing with persons (individuals, families, communities etc.) and places (cities, public monuments, religious buildings etc.) of the country of election, embedded in affectively grounded situations. One of the best entries to these feelings are personal memories of individuals, affectively tinted, explaining fears and hopes, sorrow and pride. The sensitivity for telling, i.e. affective and suggestive impressions, will be the competence to grasp not only the propositional content but above all its implicit significativity when listening to the collective narrations and individual stories of well-chosen interlocutors. Equipped with a general knowledge of the historical background of the respective 
country, the students are invited to pay attention not so much to official memory ${ }^{6}$ (kollektives Gedächtnis), but to the different perspectives of subjective memories (Erinnerungen). These stories invite the sensitive listener to incorporate himself into the affecting personal and common situations. They call for a resonant partner, not a judge.

The yield which may be expected from storytelling can even be illustrated with more depth thanks to the phenomenological differentiation between looking and listening Hermann Schmitz has proposed Schmitz, 2010, pp. 128-131). Looking is the antenna of antagonistic encorporation facilitating to take a position or to change it. Looking allows to focus on targets and, with it, limits the field of activities. Looking, finally, allows to let one's gaze wander: A background of additional affective references is integrated and contributes to let emerge feelings without a definite source.

Listening is lacking all these possibilities. It is unable to wander around; it must be picked up, e.g. by music. The hearer can't develop a defensive attitude so that the sounds become obtrusive: They can't easily be distanced like optic stimuli. But on the other hand, this profile implies specific strengths. First, the dramatic character of narration stems from the tailback of impressions around the corporeal pole of narrowness leading to swelling (Schmitz, 2010, p. 130). Schmitz calls this the historic depth of listening. Second, the obtrusiveness ${ }^{7}$ strengthens the perception of corporeal bridging qualities, i.e. suggestions of movements and synesthetic characters: The rhythm and melody of voices may have a suggestive force of attraction, but also an equal repulsive power. Narrations are a privileged channel to generate collective atmospheres, finding their source in the common European type of civilization, an implanting common situation (Schmitz, 2014, pp. 137-147).

\section{Outlook}

To participate in existing implanting European situations and to create new implanting European situations is the objective of the MONTAIGNE programme. The European type of civilization, nevertheless, is not an unchangeable content but a programme to conduct one's life in

\footnotetext{
${ }^{6}$ The official memory reflects the - controversial - political discourses to legitimize a certain collective self-image. This is one reason why the intents to write a common history for, e.g., Germany and France have met a more than reserved reception. This is not an appropriate level to promote a better understanding between peoples.

${ }^{7}$ Here, Schmitz refers to his theory of ,half things“،. Hermann Schmitz ( $\left.{ }^{2} 1995\right)$ : Der unerschöpfliche Gegenstand. Grundzüge der Philosophie, Bonn: Bouvier, pp. 216-219; Tonino Griffero (2017): Quasi-Things. The Paradigm of Atmospheres. Translated from Italian by Sarah De Sanctis. New York: Excelsior Editions.
} 
a responsible way. In this perspective, dealing with feelings as atmospheres occurs under changing conditions and may change itself the interpretation of the philosophic programme. Being aware of the tension between the two poles of discourse (Diskursabhängigkeit der Gefühle) (Landweer, 1995, p. 84) and encorporation (Einleibung as affective evidence) will be the challenge of each generation.

The strong affective tie with the country and language of election may even be completed by another type of implanting European situations: The students having run the programme in one country will sense a spontaneous complicité with other students having made the parallel parcours in another European country. With this result, a first step toward the regeneration of the European type of civilization will have been made.

\section{References}

1. Bouchard, Gérard (2016): „L'Europe à la recherche des Européens. La voie de l'identité et du mythe", Notre Europe - Institut Jacques Delors, Études \& Rapports décembre 2016: http://institutdelors.eu/wp-content/uploads/2018/01/europeidentitemythes-bouchard-ijddec16.pdf

2. Crutchfield, John / Schewe, Manfred (Hg.) (2017): Going Performative in Intercultural Education. International Contexts, Theoretical Perspectives and Models of Practice, Bristol : Multilingual Matters.

3. Daly, Herbert (2015): Essays against growthism, Bristol: WEA Books.

4. Decker, Frank (2017): „Weniger Konsens, mehr Wettbewerb: Ansatzpunkte einer institutionellen Reform”, in: Jürgen Rüttgers / Frank Decker (Hg.) (2017): Europas Ende, Europas Anfang. Neue Perspektiven für die Europäische Union, Bonn: Bundeszentrale für politische Bildung, pp. 59-76.

5. Delors, Jacques (2004): Mémoires, Paris: Plon.

6. Dufeu, Bernard (2008): „Die Bedeutung des Körpers in der Psychodramaturgie”, in : Zeitschrift für Psychodrama und Soziometrie 7, 1, SS. 50-62.

7. Dufeu, Bernard (2003): Wege zu einer Pädagogik des Seins. Ein psychodramaturgischer Ansatz zum Fremdsprachenerwerb, Mainz, Éditions Psychodramaturgiques. 
8. Even, Susanne / Schewe, Manfred (Hg.) (2016): Performatives Lehren, Lernen, Forschen - Performative Teaching, Learning, Research. Berlin: Schibri.

9. Feng, Anwei / Byram, Michael / Fleming, Mike (Hg.) (2009) : Becoming Interculturally Competent Through Education and Training, Bristol : Intercultural Matters.

10. Gehler, Michael ( $\left.{ }^{3} 2018\right)$ : Europa. Ideen - Institutionen - Vereinigung - Zusammenhalt, Reinbek: Lau;

11. Gesellschaft für Neue Phänomenologie: www.gnp-online.de.

12. Griffero, Tonino (2017): Quasi-Things. The Paradigm of Atmospheres. Translated from Italian by Sarah De Sanctis. New York: Excelsior Editions.

13. Grimm, Dieter (2016): Europa ja - aber welches? Zur Verfassung der europäischen Demokratie, München : C.H. Beck.

14. Großheim, Michael / Kluck, Steffen / Nörenberg, Henning (2014): Kollektive Lebensgefühle. Zur Phänomenologie von Gemeinschaften, Rostock: Rostocker Phänomenologische Manuskripte.

15. Honneth, Axel (2018): Anerkennung. Eine europäische Ideengeschichte, Berlin: Suhrkamp Verlag.

16. Illouz, Eva (2018): Warum Liebe endet. Eine Soziologie negativer Beziehungen, Frankfurt a.M.: Suhrkamp. (Unloving: A Sociology of Negative Relations. Oxford University Press, 2018).

17. Landweer, Hilge (1995): "Verständigung über Gefühle" », in: Großheim, Michael (Hg.) (1995) : Leib und Gefühl. Beiträge zur Anthropologie, Berlin: Akademie, SS. 71-86.

18. Landweer, Hilge (2016): „Gemeinsame Gefühle und leibliche Resonanz“, in: Undine Eberlein (Hg.) (2016): Zwischenleiblichkeit und bewegtes Verstehen. Intercorporeity, Movement and Tacid Knowledge, Bielefeld, transcript, SS. 137-174.

19. Kriechbaumer, Stefan (2014): "Ressourcenorientierung im performativen Fremdsprachenunterricht", in : Informationen des Vereins Österreichischer Verband für Deutsch als Fremdsprache / Zweitsprache 30,2, S. 22-31.

20. Latour, Bruno (2017): „Refugium Europa“, in : Heinrich Geiselberger (Hg.) (2017): Die große Regression. Eine internationale Debatte über die geistige Situation der Zeit, Frankfurt a.M., Suhrkamp, SS. 135-148. 
21. Loth, Wolfgang (2014): Europas Einigung. Eine unvollendete Geschichte, Frankfurt a.M.: Campus.

22. Macron, Emmanuel (2017) : Initiative pour l'Europe - Discours d'Emmanuel Macron pour une Europe souveraine, unie, démocratique, le 26-09-2017 (Discours à la Sorbonne): http://www.elysee.fr/declarations/article/initiative-pour-l-europe-discours-d-emmanuelmacron-pour-une-europe-souveraine-unie-democratique/

23. Merkel, Angela: Bundesregierung „Angela Merkel anlässlich der Zuerkennung der Doktorwürde honoris causa durch die belgischen Universitäten Louvain und Gent am 12. Januar 2017“: https://www.bundeskanzlerin.de/Content/DE/Rede/2017/01/2017-01-13rede-merkelehrendoktorwuerde.html;jsessionid=834F9EC7397BA248C49F58AD7D900289.s6t1

24. Mitterauer, Michael ( $\left.{ }^{4} 2004\right)$ : Warum Europa? Mittelalterliche Grundlagen eines Sonderwegs, München: C.H. Beck.

25. Müllan, Rudolf Owen \& Slaby, Jan (2011): “Introduction”, in: Hermann Schmitz (2011): Emotions outside the box - the new phenomenology of feeling and corporeality, in: Phenomenology and the Cognitive Sciences, June 2011, Volume 10, Issue 2. https://link.springer.com/article/10.1007/s11097-011-9195-1 .

26. Müller-Pelzer, Werner (2018): „Refonder l'Europe? A propos du projet politique d'Emmanuel Macron", in : impEct 9, $\underline{\text { https://www.fh- }}$ dortmund.de/de/fb/9/publikationen/impect/impect9.fb9.php

27. Müller-Pelzer, Werner (2019): Europa regenerieren. Über das Entstehen kollektiver Atmosphären (fortcoming).

28. Münch, Richard (2008): Die Konstruktion der europäischen Gesellschaft. Zur Dialektik von transnationaler Integration und nationaler Desintegration, Frankfurt a.M.: Campus.

29. Schewe, Manfred (2016): "Dramapädagogische Ansätze", in: Burwitz-Melzer, Eva / Mehlhorn, Brit / Riemer, Claudia / Bausch, Karl-Richard / Krumm, Hans-Jürgen (Hg.) (2016): Handbuch Fremdsprachenunterricht. 6., überarb. Aufl. Tübingen: Francke Verlag, SS. 354-357

30. Schewe, Manfred (2013): „Taking stock and looking ahead: Drama pedagogy as a gateway to performative teaching and learning culture", in: Scenario VII, 1, SS. 5-23; 
31. Schmitz, Hermann (2009): Kurze Einführung in die Neue Phänomenologie, Freiburg/München, Karl Alber (third edition 2012). Translations : Italian : Nuova Fenomenologia. Una introduzione, a cura di T. Griffero, Milano 2011 ; Polish : Nowa Fenomenologica. Krótkia wprowadzenie. prezl. A. Przylebski, Warschau 2015 ; French : Brève introduction à la nouvelle phénoménologie. Trad. de Jean-Louis Grosos et Philippe Georget, Paris 2016; Danish : Kort indføring i den nye fænomenologi. Oversat af Sune Frølund, Aalborg 2017 ; Romanian : Scurta Introducere in Noua Fenomenologie. Trad. de Paul Gabriel Sandu, Oradea 2018 ; Serbian : Kratki uvod u Novu Fenomenologiju. Prev. Damir Smiljanic, Novi Sad 2018.

32. Schmitz, Hermann (1997): Höhlengänge. Über die gegenwärtige Aufgabe der Philosophie, Berlin: Akademie.

33. Schmitz, Hermann (1995): Der unerschöpfliche Gegenstand, Grundzüge der Philosophie, Bonn: Bouvier.

34. Schmitz, Hermann (1988): Anaximander und die Anfänge der griechischen Philosophie, Bonn: Bouvier.

35. Schmitz, Hermann (1988): Der Ursprung des Gegenstandes. Von Parmenides zu Demokrit, Bonn: Bouvier.

36. Schmitz, Hermann (2007): Der Weg der europäischen Philosophie. Eine Gewissenserforschung, Bd. 1: Antike Philosophie, Band 2: Nachantike Philosophie, Freiburg / München: Karl Alber.

37. Schmitz, Hermann (2011): Der Leib, Berlin / Boston: de Gruyter.

38. Schmitz, Hermann (2005): Situationen und Konstellation. Wider die Ideologie totaler Vernetzung, Freiburg / München: Karl Alber.

39. Schmitz, Hermann (2010): Jenseits des Naturalismus, Freiburg / München: Karl Alber.

40. Schmitz, Hermann (2012): Das Reich der Normen, Freiburg / München: Karl Alber.

41. Schmitz, Hermann (2010): Bewusstsein, Freiburg / München: Karl Alber.

42. Schmitz, Hermann (2014): Atmosphären, Freiburg/München: Karl Alber.

43. Slaby, Jan (2016): „Kritik der Resilienz“, in: Frauke A. Kurbacher / Philipp Wüschner (2016): Was ist Haltung? Begriffsbestimmung, Positionen, Anschlüsse, Würzburg: Königshausen \& Neumann, SS. 273-298. 
44. Slaby, Jan (2010): Gefühl und Weltbezug. Eine Strukturskizze der menschlichen Affektivität, Rostocker Phänomenologische Manuskripte, Nr. 8.

45. Sloterdijk, Peter (1994 $\left.={ }^{2} 2004\right)$ : Falls Europa erwacht. Gedanken zum Programmem einer Weltmacht am Ende des Zeitalters ihrer politischen Absence, Frankfurt a. M., Suhrkamp.

46. Sloterdijk, Peter (2006): Im Weltinnenraum des Kapitals. Für eine philosophische Theorie der Globalisierung, Frankfurt a.M.: Suhrkamp.

47. Schmale, Wolfgang (2010): Geschichte und Zukunft der Europäischen Identität, Bonn: Bundeszentrale für politische Bildung, 2010 (Erstausgabe 2008).

48. Streeck, Wolfgang (2015): Gekaufte Zeit. Die vertagte Krise des demokratischen Kapitalismus, Frankfurt a.M.: Suhrkamp.

49. Trabant, Trabant (2014): Globalesisch oder was? Ein Plädoyer für Europas Sprachen, München: C.H. Beck.

50. von Arnim, Hans Herbert (2009): Volksparteien ohne Volk. Das Versagen der Politik, München, C. Bertelsmann.

51. von Arnim, Hans Herbert (2017): Die Hebel der Macht und wer sie bedient, München, Heyne Verlag, 2017. 